\title{
SMART VILLAGE - smart solution for sustainable development in the South East Region
}

\author{
Dobrotă Liviu Marian ${ }^{1}$, Mădălina Serban ${ }^{1}$, Ina Mogildea, Maria Magdalena Turek \\ Rahoveanu $^{*}$ \\ ${ }^{1}$ IMADR, "Dunărea de Jos” University of Galaţi, 80008, Galați, Romania
}

\begin{abstract}
.
Research background. An intelligent rural community in our vision wants to be a balance between people and the environment, through a transformation of long-term economic, social and environmental characteristics. This paper aims to investigate the need to change this environment in the South-East Region, Romania, a rural plain.
\end{abstract}

Purpose of the article. Villages with a certain risk of poverty are most at risk of depopulation due to the presence of low-income people, disadvantaged groups, with a population of "third age" and "fourth age". In other mountain areas, for example, there are rich villages where aging does not characterize low-income people and retired migrants.

Methods. The objectives of the research are to describe the Chiscani, Brăila area, the need to transform the villages in its composition, but also to identify activities with potential for sustainable development at its level. Awareness of the community by promoting those economic activities that support the smart plain area is the basis of the whole concept.

Findings \& Value added. The aim of this study is to evaluate the perceptions about smart village (SV) to attract entrepreneurs, tourists and business development in the South East Region, Chiscani.

Keywords: Chiscani, Smart Village, local management, marketing, branding

JEL Classification: $A 11 ; A 14 ; B 21$

*Corresponding author: mturek2003@yahoo.com 


\section{Introduction}

A number of study participants expressed concern about the challenges of the digital age, including concepts such as smart cities and smart destinations [1]; [2]; [3]; [4], which very few localities have considered so far from a smart village perspective.

The paradigm of the economic advantage of smart localities is supported, which would consist of creating those activities, infrastructure from the corporate sector and from this more obvious in localized management and marketing. [5], in the latest papers support partnerships [6] and collaborative planning with a common strategic vision [7].

All this, of course, implies a more pro-active approach of partnerships in the process of transformation to the new smart village concept [8] but also a multidimensional view of places.

Moreover, the marketing aspects of the localities to which the participants in this study referred, which mark the products as those sophisticated mechanisms to represent the complexity of the actions. Various practitioners have repeatedly acknowledged that spatial planning strategy can act as a catalyst in smart village application.

Our smart village premise is to associate strategy planning with the involvement of local actors, citizens, policy makers and organizations in identifying actions that lead to sustainable local autonomy.

\section{Methods}

In this paper, we aim to evaluate the current perspectives of the implementation of SV in Romania based on the interest of the community and the desire to install it. To achieve this, three main objectives have been formulated:

(1) segmenting the community based on the need or desire to modernize the community in the future under different conditions (financial or informative);

(2) description and evaluation of the SV manager's profile;

(3) evaluation of preferred communication channels in the digital market.

We want to emphasize that we focus on social media users, open to new technologies and innovations in their activities. Because they use the Internet on a daily basis and are familiar with mobile applications, they are seen as potential users of SV and other specific technologies and actions [9], [10], [11].

Although there are not already a large number of published studies on various aspects of the SV concept, our paper focuses on an area in Romania - with potential fishing and a potential group of future entrepreneurs using SV and its combined actions.

Based on the literature review [17], [18], [19] we assume that the following variables may have an impact on the positive assessment and community interest for SV: expecting economic transformations, (due to reduced energy consumption in terms of identifying investments in this sense), the feeling of being pro environmental due to energy saving, the emergence of new ideas, knowledge about the benefits of the local SV network. In addition to these parameters, we expect economic and social attributes, such as income or education, legal regulations (support for promoting the concept of SV from government or local authorities), research related to SV, wi-fi / internet connection, ownership different smart devices (eg smart plugs, smart appliances) and social influence (positive support or experience among family members (Fig.1) 


\section{Results and discussions}

As shown in Fig.1, the main conditions for the development of the smart village concept [20] depend on the use of information transmission techniques and technologies. In this context, a community with creative thinking and open to change, focused on improving the quality of life, is a major gain for the promotion and development of this concept.
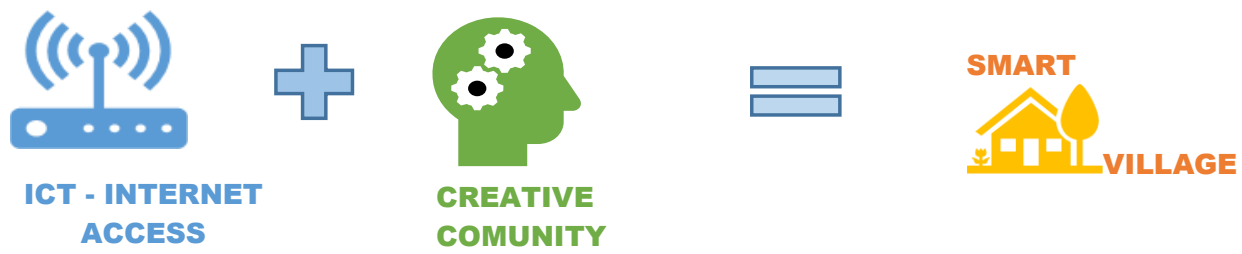

Fig. 1. The key elements for the development of the smart village concept

It is topical that more and more attention is paid to the participation of local communities and their ideas in creating a modern village [21], and creativity and openness to the new, to change, must come from both residents and their representatives, or councilors of communes or mayors. So, local authorities must make efforts to live up to the expectations of the local community by creating villages with visible changes in terms of quality of life.

\subsection{Data collection and sample}

To collect the data, we designed an online questionnaire, which allowed respondents to answer our questions anonymously. The questionnaire consisted of 59 questions, each with appropriate answer options (eg yes or no). This questionnaire was hosted on a web page, and user sessions were watched by Isondaje. The anonymity of the users was achieved because we did not have access to the IP addresses of the respondents through Surveys. As the purpose of the study was to obtain answers from Romanian social users, the link to the questionnaire with adequate graphics was distributed through social platforms.

According to surveys, 213 users have completed the survey out of 500 so far. The average time spent by these users was 3 minutes on the website.

\subsection{Initial data set analysis}

The respondents are primarily young men (64.6\%) aged between 18 and 35 years $(69.6 \%)$, without children or with only one child $(78.3 \%)$. In their families, there are three or four people $(54.5 \%)$, but almost half of them are single people $(49.8 \%)$. Their place of residence is in the city $(86.6 \%)$, and their education is at least secondary $(82.9 \%)$. Over $50 \%$ of them work full time, and $16.5 \%$ run their own business. The highest percentage of these $(44.2 \%)$ achieves incomes of up to 4,000 lei, but a fairly large group has a monthly income between 5,000 and 10,000 lei (17.8\%). Most of them spend up to 2000 lei per month $(30 \%)$ on utilities. 
According to a report by [22] in Romania, 23\% of household expenditure is allocated to gas, water, electricity or fuel, which means that Romanians are below the average in Finland (28.8\%), Denmark (28.7\% ) United Kingdom (26.7\%), followed by France (26.2\%), Sweden $(26.1 \%)$ and the Czech Republic (25.4\%). At the opposite end of the scale, Malta (10.1\%), Lithuania (14.8\%) and Cyprus $(15.4 \%)$ have the lowest share of household expenditure. This percentage represents the most important element of household expenditure in the EU, before transport (13\%), food and non-alcoholic beverages $(12.2 \%)$, restaurants and hotels $(8.8 \%)$ and culture $(8.5 \%)$.

Regarding the analysis of respondents' assets, the survey showed that respondents most often have their own smartphone and laptop $(86.3 \%, 68.3 \%)$, have Wi-Fi or internet connection at home $(96.68 \%)$, but only $38.6 \%$ of them have other devices that connect to the internet.

New information about utilities most often comes from television programs $79.7 \%$ and newspapers $44.1 \%$. Information about SV comes mainly from newspapers $28.1 \%$, TV programs on this topic $20.2 \%$, and radio $15.4 \%$. Some of the respondents did not hear about this concept and the chances of success of SV in households $26.1 \%$.

Respondents' attitudes towards the role of government in the development of SV, their preferences and fears about CS. In particular, respondents expressed a preference to save energy, almost $80 \%$ of which would like to reduce energy, water and gas consumption $82 \%, 81.9 \%, 77.8 \%$ to reduce costs and waste $80,8 \%$, given that this has an impact on utility prices $76.4 \%$. health.

At the same time, up to $36.9 \%$ believe that SVs could have a negative impact on their

Most people do not know what a SV $54.9 \%$ is, but after completing the survey, the vast majority of them said they would seek information on this topic $83.6 \%$. Only $15 \%$ of respondents installed SV in their home, a third intend to install SV $32.9 \%$.

At the end of the analysis, the following typology resulted:

Model 1: Consumers who have already installed SV in their household.

Model 2: Consumers who already know about SV and are in the process of installing it in their household

Model 3: Consumers who are only looking for information about SV and would like to install SV in their household

Model 4: Consumers who care about financial savings due to the installation of SV

Model 5: Consumers who care about information and advice about SV.

The construction of five consumer models based on their segmentation and profiles allows us to observe the differences between consumers: who have already installed SV (model 1), who are in the process of installing SV in their household (model 2) and who would like to have SV in the future (model 3).

In addition, two models have been identified that benefit from potential benefits: financial (model 4) and informative (model 5).

First, we noticed that community members who have knowledge about SV and the smart grid (model 1) care about the experience and opinion of their friends and acquaintances about SV.

Then, the community that are in the process of installing SV are mainly those who have a business, or who are employed.

Again, the social influence that friends or relatives have already installed PS in their household has a strong impact on the community's decision to install SV.

At the same time, however, the information about which friends or relatives intend to participate in such a network has a much smaller impact. These consumers want to collect information about PS and / or smart grids from various seminars or educational workshops. 
Finally, consumers who have neither installed SV nor are in the process of installing, but would like to have SV in the future (model 3) are those who do not have a job. They search for SV information on professional websites and social networks, such as LinkedIn, to learn how to save energy and pay lower electricity bills. This result primarily involves the urban population, which makes up the majority of respondents in this study. Currently, the pilot program on SV is mainly in the area of potential where a high percentage of small businesses are registered. Therefore, it would be useful to use such professional social networking platforms to disseminate information on SV.

\section{Conclusions}

The construction of five consumption models based on their segmentation and profiles allows us to observe the differences between consumers: who have already installed SV (model 1), who are in the process of installing SV in their household (model 2) and who would like to have SV in the future (model 3).

In addition, two potential benefits have been identified: financial (model 4) and informational (model 5).

First, we noticed that community members who have knowledge about PS and the smart grid (model 1) care about the experience and opinion of their friends and acquaintances about SV.

Then, the community that is in the process of installing SV is mainly those who have a business or are employed.

Again, the social influence that friends or relatives have already installed SV in their household has a strong impact on the community's decision to install SV.

At the same time, however, the information about which friends or relatives intend to participate in such a network has a much smaller impact. These consumers want to collect information about SV and / or smart grids from various seminars or educational workshops.

Finally, consumers who have not installed SV and are not in the process of installing, but would like to have SV in the future (model 3) are those who do not have a job. They search for SV information on professional websites and social networks, such as LinkedIn, to learn how to save energy and pay lower electricity bills. This result primarily involves the urban population, which represents the majority of respondents in this study. Currently, the SV pilot program is mainly in the potential area where a high percentage of small businesses are registered. It would therefore be useful to use such professional social networking platforms to disseminate information about the SV.

\section{References:}

1. Belanche, D.; Casaló, L. V.; Guinalíu, M. Website usability, consumer satisfaction and the intention to use a website: The moderating effect of perceived risk. J. Retail. Consum. Serv. 2012, doi:10.1016/j.jretconser.2011.11.001.

2. Boes, K.; Buhalis, D.; Inversini, A. Smart tourism destinations: ecosystems for tourism destination competitiveness. Int. J. Tour. Cities 2016, doi:10.1108/IJTC-12-2015-0032.

3. Medway, D.; Swanson, K.; Neirotti, L.D.; Pasquinelli, C.; Zenker, S. Place branding: Are we wasting our time? Report of an AMA special session. J. Place Manag. Dev. 2015, doi:10.1108/JPMD-12-2014-0028.

4. Vanolo, A. The image of the creative city: Some reflections on urban branding in Turin. Cities 2008, doi:10.1016/j.cities.2008.08.001.

5. Kalandides, A.; Kavaratzis, M.; Boisen, M.; Kavaratzis, M. From "necessary evil" to necessity: Stakeholders' involvement in place branding. J. Place Manag. Dev. 2012, doi:10.1108/17538331211209013.

6. Govers, R.; Go, F.M.; Kumar, K. Promoting tourism destination image. J. Travel Res. 2007, 
doi: $10.1177 / 0047287507302374$.

7. Healey, P. The treatment of space and place in the new strategie spatial planning in europe. In Contemporary Movements in Planning Theory: Critical Essays in Planning Theory: Volume 3; 2017 ISBN 9781351949101.

8. Braun, E.; Kavaratzis, M.; Zenker, S. My city - my brand: The different roles of residents in place branding. J. Place Manag. Dev. 2013, doi:10.1108/17538331311306087.

9. Droge, C.; Vickery, S.K.; Jacobs, M.A. Does supply chain integration mediate the relationships between product/process strategy and service performance? An empirical study. Int. J. Prod. Econ. 2012, doi:10.1016/j.ijpe.2012.02.005.

10. Malinen, S.; Ojala, J. Maintaining the instant connection-social media practices of smartphone users. In Proceedings of the From Research to Practice in the Design of Cooperative Systems: Results and Open Challenges - Proceedings of the 10th International Conference on the Design of Cooperative Systems, COOP 2012; 2012.

11. Lipschultz, J.H. Free expression in the age of the Internet: Social and legal boundaries; 2018; ISBN 9780429968921.

12. Long, J.O. Service design. In SpringerBriefs in Computer Science; 2012.

13. Amblee, N.; Bui, T. Harnessing the influence of social proof in online shopping: The effect of electronic word of mouth on sales of digital microproducts. Int. J. Electron. Commer. 2011, doi:10.2753/JEC1086-4415160205.

14. Nolan, M.; Brown, J.; Davies, S.; Nolan, J.; Keady, J. The Senses Framework: improving care for older people through a relationship-centred approach. Getting Research into Practice (GRiP) Report No 2.; 2006;

15. Bollinger, B.; Gillingham, K. Environmental preferences and peer effects in the diffusion of solar photovoltaic panels. J. Mark. Sci. 2012.

16. Chawla, Y.; Kowalska-Pyzalska, A.; Silveira, P.D. Marketing and communications channels for diffusion of electricity smart meters in Portugal. Telemat. Informatics 2020, doi:10.1016/j.tele.2020.101385.

17. Gerpott, T.J.; Paukert, M. The relationship between employee satisfaction and customer satisfaction: A meta-analysis. Zeitschrift für Pers. 2011, doi:10.1688/18620000_ZfP_2011_01_Gerpott.

18. Dhingra, $\bar{M}$.; Chattopadhyay, S. Advancing smartness of traditional settlements-case analysis of Indian and Arab old cities. Int. J. Sustain. Built Environ. 2016, doi:10.1016/j.ijsbe.2016.08.004.

19. Kowalska-Pyzalska, A.; Byrka, K. Determinants of the willingness to energy monitoring by residential consumers: A case study in the city of Wroclaw in Poland. Energies 2019, doi:10.3390/en12050907.

20. Rahoveanu, M.M.T.; Zugravu, A.G. Online marketing - Communication strategy for managers AquaPonics farms. In Proceedings of the Proceedings of the 28th International Business Information Management Association Conference - Vision 2020: Innovation Management, Development Sustainability, and Competitive Economic Growth; 2016.

21. Calzada, I. (Smart) citizens from data providers to decision-makers? The case study of Barcelona. Sustain. 2018, doi:10.3390/su10093252.

22. Stan, S.; Medrega, C. Tax Authorities' Attitude Hinders Improvement Of Romania's Economic Competitiveness. Ziarul Financ. 2014.

23. Booth, P.; Chaperon, S.A.; Kennell, J.S.; Morrison, A.M. Entrepreneurship in island contexts: A systematic review of the tourism and hospitality literature. Int. J. Hosp. Manag. 2020, doi:10.1016/j.ijhm.2019.102438. 